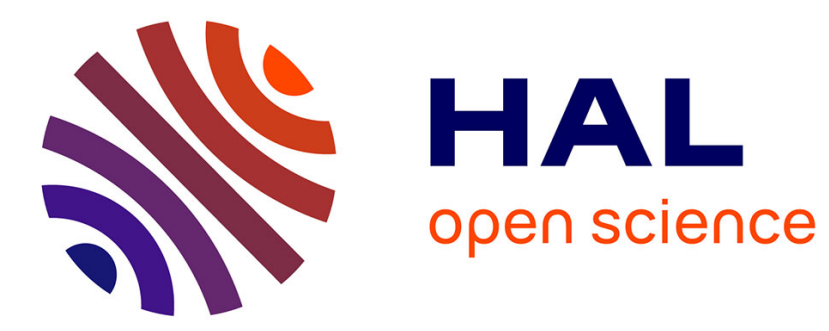

\title{
Bird community conservation in large blocks of mountain pine
}

\author{
Françoise Lescourret, Michel Génard
}

\section{To cite this version:}

Françoise Lescourret, Michel Génard. Bird community conservation in large blocks of mountain pine.

Environmental Conservation, 1993, 19 (4), pp.359-361. hal-02705832

\section{HAL Id: hal-02705832 \\ https://hal.inrae.fr/hal-02705832}

Submitted on 1 Jun 2020

HAL is a multi-disciplinary open access archive for the deposit and dissemination of scientific research documents, whether they are published or not. The documents may come from teaching and research institutions in France or abroad, or from public or private research centers.
L'archive ouverte pluridisciplinaire HAL, est destinée au dépôt et à la diffusion de documents scientifiques de niveau recherche, publiés ou non, émanant des établissements d'enseignement et de recherche français ou étrangers, des laboratoires publics ou privés. 


\section{SPECIFIC REPLACEMENT}

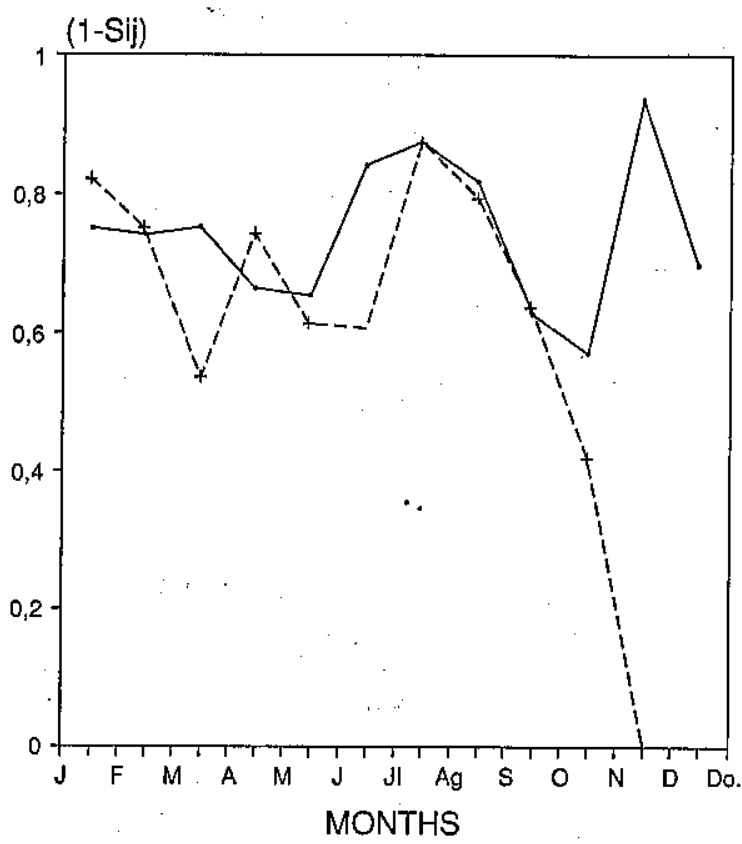

FIG. 1. Year's variation in specific richness at Bejarano Stream and Guadiato River

greater than $250 \mathrm{~m}$ on average, (c) the climax vegetation of both belongs to the same Alliance, and (d) the physico-chemical characterization of the substrates revealed no significant differences, the altered environment of the second sampling station must be the root of the marked differences found in the Carabidae communities studied.

In our opinion, the structural changes observed seem to be responses of the biological system towards maintaining a stable population in a highly fluctuating habitat. According to our results, the carabid fauna associated with the Guadiato River basin was originally composed of ubiquitous species of stable media - mostly apterous that gave way to other, less selective species which were better adapted to colonize a fluctuating environment as the alterations caused by the river 'correction' and anthropogenization gradually developed.

\section{REFERENCES}

DAY, K.R. (1987). The species and community characteristics of Ground Beetles (Col. Carabidae) in some Northern Ireland Nature Reserves. Proceedings of the Royal Irish Academy (Sec. $B$, Biological, Geological and Chemical Science), 87B(4), pp. $65-82$.
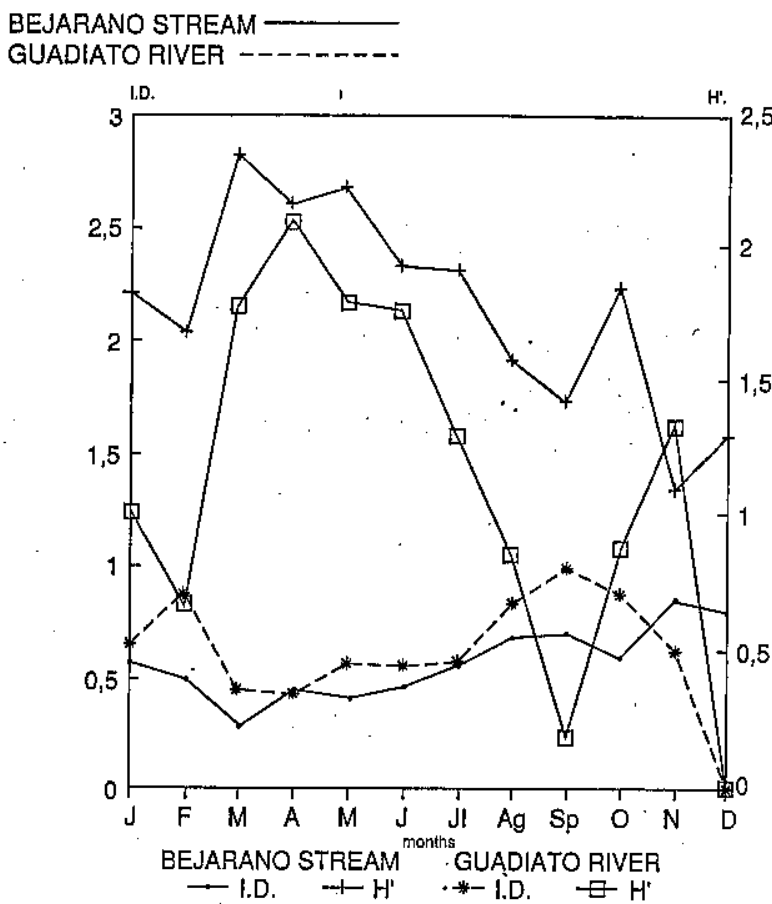

FIG. 2. Year's variation in specific replacement index at Bejarano Stream and Guadiato River.

DAY, K. R. \& CARThY, J. (1988). Changes in Carabid Beetle communities accompanying a Rotation of Sitka Spruce. Agr. Ecosys. and Envir., 24, pp. 407-15.

DIJK, T.H.S. VAN (1986). Changes in the Carabid fauna of a previously agricultural field during the first twelve years of improvising treatments. Netherlands Journal of Zoology, 36(4), pp. 413-37.

KromP, B. (1989). Carabid beetle communities (Carabidae: Coleoptera) in biologically and conventionally farm and agroecosystems, Agric. Ecosys. and Envir., 27, pp. 241-51.

MARGALEF, R. (1974). Ecologia. Ed. Omega, Barcelona, Spain: 951 pp., illustr.

SoUTHWOOD, T.R.E. (1978). Ecological Methods with Particular Reference to the Study of Insect Populations. Chapman \& Hall, London, England, UK: 524 pp., illustr.

\section{ANA MaRIA CARDENAS $\&$ \\ CARMEN BACH \\ Departamento de Biologia Animal Facultad de Ciencias Universidad de Córdoba E-14071 Córdoba Spain.}

\section{Bird Community Conservation in Large Blocks of Mountain Pine}

\section{Introduction}

Mountain Pine (Pinus uncinata Ram.) forests occupy only a very small part of Europe, being practically limited to the subalpine zone of the Alps and of the Pyrenees between 1,600 and $2,400 \mathrm{~m}$. However, they are of great ecological interest, especially concerning bird communities which develop local adaptations or include rare species (Génard \& Lescourret, 1985, 1987).
In the Pyrenees, the Mountain Pine forest is broken into large 'blocks' mainly by human activities - especially domestic animals' grazing, which was intensive up to the eighteenth century (Métailié, 1987). The blocks vary in size, habitat features, and degree of connection with open areas. All these factors are likely to influence bird population composition.

The conservation of the bird communities of the Pyrenean Mountain Pine forest requires knowledge of the 
relationships between bird population composition and these block characteristics, in order to help land managers in choosing the type of block to be protected. In this paper, we study these relationships and the implied suggestions for conservation purposes.

\section{Methods}

Seven Mountain Pine blocks were chosen, each located on a different mountain and distributed along the length of the Pyrenees. They had similar disturbance regimes (causative mechanisms of patches, here chronic grazing), forest age, and boundary discreteness (boundaries with lower-forest types or open areas were always abrupt). The areas ranged from 1.5 to $265 \mathrm{~km}^{2}$.

Birds were censused in spring, using the point-count technique (Blondel et al., 1981), which indicates the presence or absence of species per point. A sample (set of points recorded through a year in an homogeneous part of a block) provided a list of frequency of occurrence by species (number of points where species were contacted per total number of points). For some forest blocks, the census was repeated in time (several years) and space (different parts of the blocks), yielding a total of 18 samples from 357 points. The data were collected by different observers (M. Clouet, P.A. Dejaifve, M. Leconte \& F. Spitz, pers. comm. \& cf. Espeut, 1984), and by ourselves.

Habitat variables (Table I) were measured from topographic maps. (altitude) and recorded during censuses. Block area was measured from topographic maps. The importance of the connection between Mountain Pine blocks and lower forested blocks or open areas was expressed through the ratio 'area of Beech [Fagus sylvatica] and Silver Fir [Abies pectinata] connected to Mountain Pine/ Mountain Pine block area + area of Beech and Fir connected to Mountain Pine'. A zero value of this connection index corresponded to no connection between Mountain Pine and other forests, and a full connection between Mountain Pine and open areas. A value near 1 corresponded to a full connection between the Mountain Pine block and a much larger area of Beech and Fir forest.

To summarize the variation in bird-community composition among the Mountain Pine blocks, we performed a correspondence analysis on the basis of frequencies of occurrence of the 29 censused bird species obtained in the 18 samples. Correspondence analysis does not require any hypothesis on data distribution. Relationships between this variation and habitat, block area, and connection variables, were studied by step-wise multiple regression of the highest-ranking components of the correspondence analysis, which depicted the significant part of the variation. The patterns of the species on these components were examined.

\section{Results}

The first two factors of the correspondence analysis accounted for $45 \%$ of the total variation. The percentages of explained variation for each of the remaining factors were weak relatively to $\mathrm{F} 1$ or $\mathrm{F} 2$. F1 was explained essentially by the connection index (R2=0.71, $\mathrm{p}<0.001)$. The connection of Mountain Pine with forests of lower altitude decreased along F1 following the sign of the regression coefficient. $\mathrm{F} 2$ was explained by canopy height $(\mathrm{R} 2=0.65, \mathrm{p}<0.001)$. Canopy height increased along $\mathrm{F} 2$, following the sign of the regression coefficient. Block area was not selected by the regression process of $\mathrm{F} 2$ in spite of having a high simple correlation with this axis (0.66). It was correlated with canopy height $(0.64)$.

Samples from Mountain Pine blocks isolated from low-altitude forests, and with low canopies, had the lowest species richnesses, but bird species, including high-altitude species and typical mountain Pine species (cf. Joachim et al., 1990), obtained their highest frequencies there. Four of these typical Mountain Pine species are rare in France: Carduelis spinus, Loxia curvirostra, Serinus citrinella, and Turdus torquatus ( $c f$. Yeatman, 1976). On the contrary, increasing canopyheight or connection with low-altitude forests favoured species richness, but decreased the occurrence of typical Mountain Pine species.

\section{Discussion and Conclusions}

Canopy height was found to influence the variation of the bird composition in the Pyrenean Mountain Pine blocks, especially favouring species-richness. On the contrary, block area did not seem to have any effect, despite its high variability. However, strong correlations existed between these two variables. Concerning fragmented habitat studies set up at a similar scale, some showed habitat features to be the principal direct control of bird community structure (Johnson, 1975), while others included habitat and area as determinants of animal communities (Thompson, 1978). Others, again, which at first emphasized area effects (Vuilleumier, 1970), finally concluded that species numbers could be equally correlated with either area or habitat (Vuilleumier \& Simberloff, 1980). It now appears that definite arearelated distributions might be largely a consequence of high concordance between area and habitat.

The connection of Mountain Pine blocks with other forest patches was demonstrated to be a chief point of variation in bird composition. Similar inter-patch connection effects have rarely been mentioned at such a geographical scale (but see Décamps et al., 1987). This effect was an enrichment of the Mountain Pine community by means of species with their main habitat in low- and medium-altitude forests.

Following these results, two ways can be suggested for the conservation of bird communities in Pyrenean Mountain Pine forests. If land managers focus on the conservation and the development of a typical MountainPine forest community and of rare species, their effort must turn to the protection of Mountain Pine blocks which have become isolated from low-altitude forest and have low canopies. If they focus on species richness, their effort must turn to the protection of Mountain Pine blocks

\section{TABLE I}

Variables Used to Investigate the Differences between the Mountain Pine Breeding-bird Samples.

Mean altitude (m)

Canopy height

Plant cover of the different vertical strata $(\%)$ :

$0-0.5 \mathrm{~m} ; 0.5-1 \mathrm{~m} ; 1-4 \mathrm{~m} ; 4-8 \mathrm{~m} ;>8 \mathrm{~m}$

Mountain Pine block area $=$ PBA $\left(\mathrm{km}^{2}\right)$

Connection index: area of Beech and Fir connected to Mountain. pine/ PBA + area of Beech and Fir connected to Mountain Pine. 
that are connected with low-altitude forest or have high canopies. Surely, these purposes are not inconsistent with each other, but limited means may force choices.

\section{Acknowledgements}

Thanks are due to the French Environment Ministry (SRETIE service), from which a grant was received for this work, and to J. Blondel, who encouraged this project.

\section{REFERENCES}

Blondel, J., Ferry, C. \& Frochot, B. (1981). Point counts with unlimited distance. Studies in Avian Biology, 6, pp. 414-20, illustr.

DECAMPS, H., JOACHIM, J. \& LAUGA, J. (1987). The importance for birds of the riparian woodlands within the alluvial corridor of the River Garonne, SW France. Regulated Rivers: Research and Management, 1, pp. 301-16, illustr.

EsPeUT, M. (1984). Avifaune Nicheuse du Massif de Madres et du Mont Coronat. Thèse de 3 ème cycle, Université de Montpellier, France: $231 \mathrm{pp}$., illustr.

GÉNARD, M. \& LESCOURRET, F. (1985). Caractères insulaires de l'avifaune forestière des Alpes du Sud et des Pyrénées Orientales. Oecol. Gener., 6, pp. 209-21, illustr.

GÉNARD, M. \& Lescourret, F. (1987). The Common Crossbili Loxia curvirostra in the Pyrenees: some observations on its habitats and on its relations with conifer seeds. Bird Study, 34, pp. 52-63, illustr.

JoAchim, J., Clouet, M., Bousquet, J.F. \& Faure, C. (1990). Peuplements d'oiseaux nicheurs des forêts pyrénéennes centrales: comparaison du peuplement de différentes essences. Acta Biol. Mont., 10, pp. 135-7, illustr.

JoHNSON, N.K. (1975). Controls of number of bird species on montane islands in the Great Basin. Evolution, 29, pp. 545-67, illustr.
MÉTAilí, J.P. (1987). The degradation of the Pyrenees in the nineteenth century: an erosion crisis? $\mathrm{Pp}$. 533-44 in International Geomorphology 1986 Part II (Ed. V. GARDINIER). John Wiley \& Sons Ltd, London, England, UK: [not available for checking].

THOMPSON, L.S. (1978). Species abundance and habitat relations of an insular montane avifauna. Condor, 80, pp. 1-14, illustr.

VUILLEUMier, F. (1970). Insular biogeography in continental regions: I, The northern Andes of South America. Am. Nat., 104, pp. 373-88, illustr.

VUILLEUMIER, F. \& SIMBERLOFF, D. (1980). Ecology versus history as determinants of patchy and insular distributions in High Andean birds. Evol. Biol., 12, pp. 235-79, illustr.

YEATMAN, L. (1976). Atlas des Oiseaux Nicheurs de France. Société Ornithologique de France, Ministère de l'Environnement, Paris, France: xvi + 282 pp., illustr.
FRANÇOISE LESCOURRET
Centre de Biologie des Ecosystèmes d'Altitude
Université de Pau
Avenue Louis Sallenave
F-64000 Pau, France,
$\&$
MICHEL GÉNARD
Groupe d'Etude et de Recherche
en Ecologie Appliquée
en Ecologie Appliquée
U.E.R. de Biologie
Avenue des Facultés
F-33405 Talence Cedex (2)
France.

\section{Akpatok Island Revisited}

Our main purpose in spending some days on Akpatok Island $\left(c .60^{\circ} 25^{\prime} \mathrm{N}, 68^{\circ} 10^{\prime} \mathrm{W}\right.$ in Ungava Bay, NE Canada) in August 1992 was to verify the existence of a valley described by Sydney R. Montague in I Lived with the Eskimos, Jarrolds, London, 1940, xiv + 223 pp., illustr. Of it he wrote (page 183):

'They were the dried skulls of men. A score lay in' a group. I looked further; there were leg bones and bones of arms, hands, fingers and feet, scattered and tossed about, smoothed to the appearance of old ivory by years of exposure to hard weather'.

Montague visited the island about 1929. The Oxford University Exploration Club's Expedition of 1931 to Akpatok mapped the island and did not mention any such valley of bones. Akpatok is 28 miles ( $45 \mathrm{~km}$ ) long and 14 miles $(23 \mathrm{~km})$ wide, surrounded almost completely by vertical cliffs. Access to the island by boat is practicable only in limited places where ravines reach sea-level or where the cliffs are replaced by a series of raised beaches (see Fig. 1).

\section{Still Visited Mainly to Hunt Walrus}

The modern 'Inuit'* visit Akpatok in August to hunt Walrus (Odobaenus rasmarus), as the island lies on a major Walrus migration-route. During the hunt, the hunters are much too busy to go far inland, and moreover prevalence of Polar Bears (Thalarctos maritimus) on the Island makes unorganized camping and exploring somewhat dangerous. While falling off the cliffs or being

* The seemingly preferred modern name collectively for Eskimos (Fr. 'Esquimaux'). - - Ed.

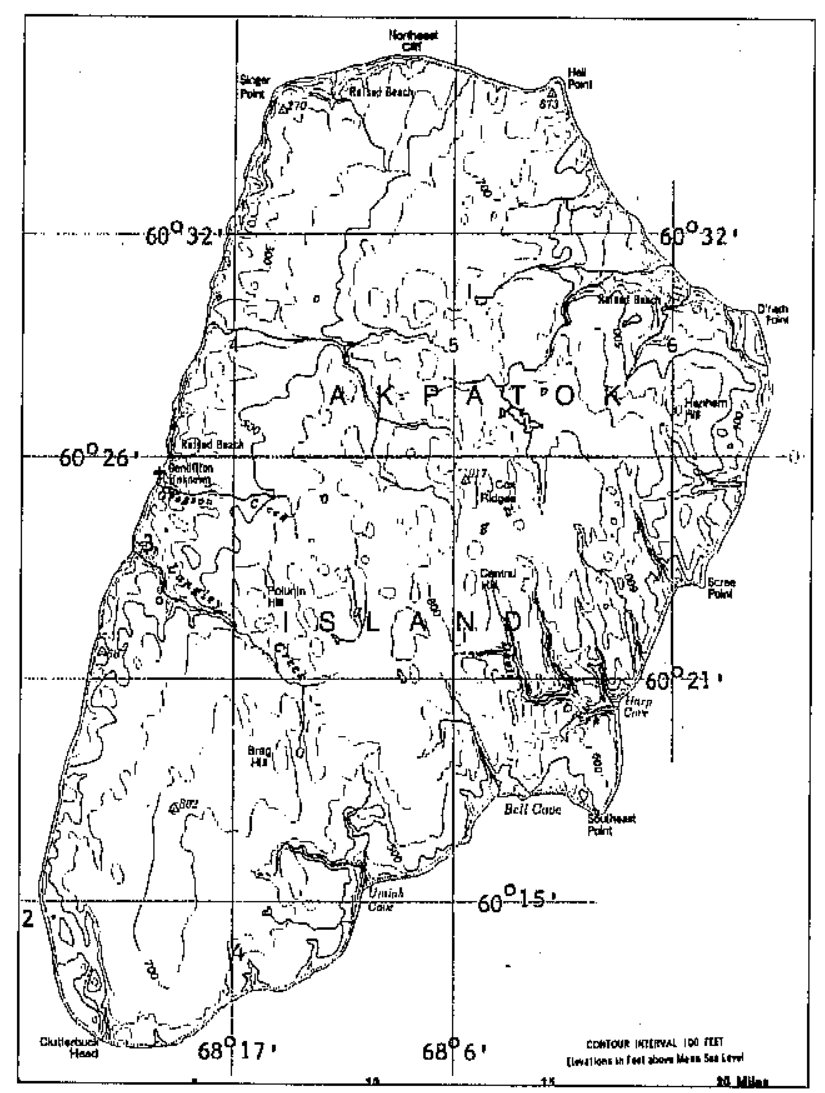

Fig. 1. This map is based on information taken from the National Topographic System map-sheet number NTS $25-B$ \& C Akpatok [Concluded overleaf] 
[Continued from foot of preceding column]

Island edition 2 (c) 1983: Her Majesty the Queen in Right of Canada with permission of Energy, Mines and Resources Canada. The drillsite is marked with the airplane and the words 'Condition Unknown'. The numbers ' 2 ', '3', and '4', are the locations of the photographs constituting Figs 2, 3, and 4, respectively.

attacked by a Polar Bear seems dangerous, an even bigger danger is getting lost. The size of the island and its uniform topography render travelling by compass practically obligatory, especially as fog often limits visibility. During our recent visit* we had to find our way back to camp in a snowstorm in August which limited visibility to 100 feet $(c$. $30 \mathrm{~m}$ ). Our guide, Jusipi Keleutak, told us that very few of the men and almost none of the women had visited the Island. He himself had only been on the west coast, having helped in an oil-drilling project in 1971. The island evokes mystery even today among the Inuit, who were always very interested in us when we were introduced as having come to visit Akpatok.

The Walrus hunt was very successful, five Walruses being shot in less than two hours. It was much more work to process the carcasses of one-two tons each than to kill the animals. There seemed to be plenty more Walrus swimming around in groups of 5 to 10 individuals.

\section{Island Mainly Still Pristine}

The internal plateau of the island was still pristine. We saw no trash, motorcycle tracks, or even cairns, though we walked over a fairly large portion of the island. We saw one Ptarmingan (probably Lagopus lagopus ungavus), two caterpillars, two spiders, but no Polar Bears - though we did see a den which the guide said was not too fresh. Of course we saw millions of auks. We were impressed by the tremendous flights from cliffs at the south end when Jusipi fired his gun. Apparently the crew was impressed as well, as they fired off guns whenever the boat passed anywhere near to bird-cliffs. The colonial sea-birds appeared to be various auks, murres, and guillemots, and it is comforting also to note that the interior of Akpatok remains much as Nicholas Polunin described it in 1931 (in his The Isle of Auks, published in 1932 by Edward Arnold \& Co., London, England, UK: 253 pp., illustr.). Thus we found the 'lush green valley' he described on the western side. We also found more 'Omiak' (Pedicularis lanata) with the fat edible root which he mentioned in particular.

On the narrow beach of the west coast we saw one fox ${ }^{\dagger}+$ which the crew circled back to shoot when we told them about it. The manured scree under the bird-cliffs supported lush Scurvy-grass $\S$ (Cochlearia sp.) or 'northern rhubarb' (Inuit: Qunguliq), and the crew collected three garbage-bags of it to take back. Polunin referred to these lush green-covered screes and made it a priority to get down to them (Fig. 2).

\section{But Not Everywhere}

The entry-points to the interior are becoming trashed. The concern drilling for oil left barracks which are still

\footnotetext{
*The members of our party were Professor Irvin Roy Hentzel,
} Gene Steiner, Patricia Steiner, Robert Hentzel, Stuart Nelson, Dr Normand Tremblay, and Jusipi Keleutak (guide). The outfitter was Bob Deer of Quartaq, Canada. We spent 8-11 August 1992 on the Island.

Probably the local subspecies of the Arctic Fox (Alopex lagopus ungavus). - Ed.

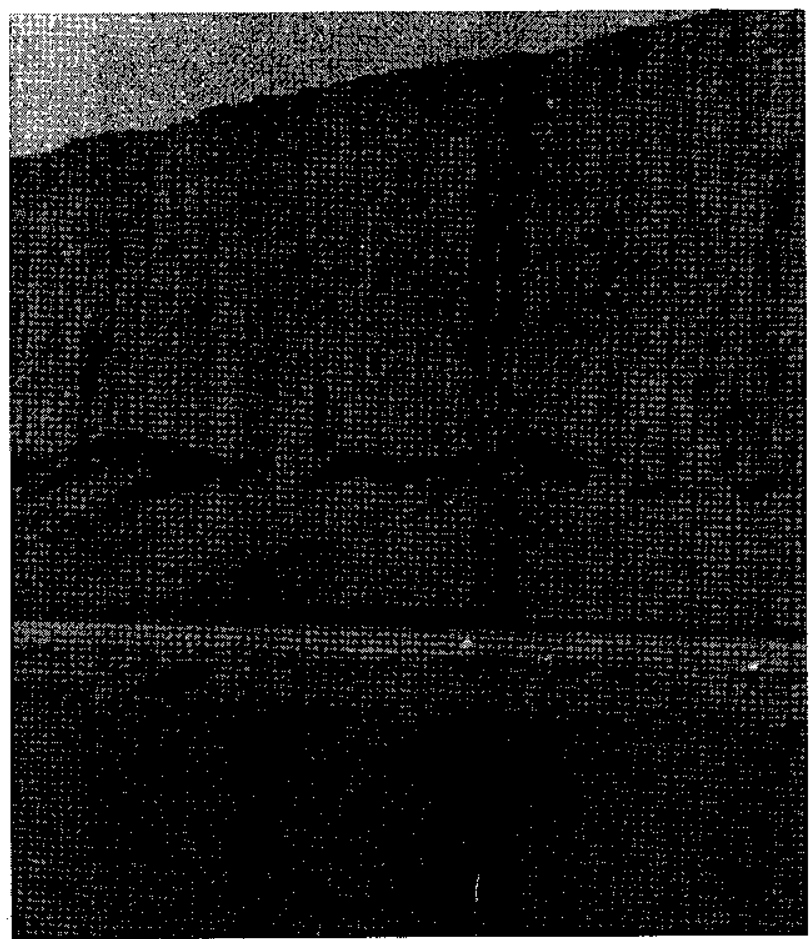

FIG. 2. The cliff-face on the southwest coast of Akpatok. The members of ship's crew are barely visible on the beach. They have landed to gather Scurvy-grass (Cochlearia sp.) or 'Northern Rhubarb' which is the dark vegetation growing at the base of the cliff where it is manured by the droppings of the birds nesting high above, along the cliff-face. Photo: S. Nelson.

liveable. The drillers also left part of their drilling equipment as well as barrels (presumably imported for fuel) which are slowly rusting. I rolled one barrel a bit and it started leaking-out oil which smelled like kerosene. As empty barrels would have been easily blown away, I suspect that these rusty barrels were all at least partially full. Perhaps when they rust enough to lose all their contents, they will blow away and the drill-site will be free of them. We found rusty tin-cans in the entries to ravines as well as other trash. The guide discovered the remains of a crashed helicopter. We found out later that the helicopter contained a pilot and a biologist who had just shot a tranquilizer into a Polar Bear when the crash occured. The pilot and biologist were not injured, but watched in horror as the Bear slowly recovered and then circled around and around their crashed helicopter.

\& Presumably the highly polymorphic Common Scurvy-grass (Cochlearia officinalis s.1.) but just possibly a member of the Sorrel Family, namely Mountain Sorrel (Oxyria digyna), which is also common on sea-shores practically throughout the Canadian Arctic Archipelago though less favoured by manuring than Scurvy-grass (belonging to the Mustard and Cabbage Family) - cf. N. Polunin, 'The Flora of Akpatok Island, Hudson Strait', Journal of Botany, LXXII, pp. 197-204, 1934; 'The vegetation of Akpatok Island, Part I', Journal of Ecology, XXII, pp. 337-95, illustr., 1934; ibid. 'Part II', Jounal of Ecology, XXIII, pp. 161-209, illustr., 1935; Botany of The Canadian Eastern Arctic, Part I: Pteridophyta and Spermatophyta, Canada: Department of Mines and Resources, National Museum Bulletin Nr 92, vi + 408 pp., illustr. + folding map, 1940; ibid. Part III: Vegetation and Ecology, Canada: Department of Mines and Resources, National Museum Bulletin Nr 104, viii + 304 pp., illustr, + folding map, 1948; Circumpolar Arctic Flora, Clarendon Press, Oxford, England, UK. xxviii +514 pp., c. 1,000 illustrs, 1959; etc. - Ed. 